\section{LETTERS TO THE EDITORS}

The Editors do not hold themselves responsible for opinions expressed by their correspondents. No notice is taken of anonymous communications

\section{Observations on the Administration of BAL-Intrav to Man}

IN their original communication about BAL-Intrav, Danielli, Danielli, Mitchell, Owen and Shaw ${ }^{1}$ referred to some of the work on man which we had at that time begun. Since we have been forced to abandon this work for the time being, owing to the desirability of studying some of the nutritional problems in Germany, we have decided to publish our preliminary observations for the beneflt of those who may be interested in the subject.

The BAL-Intrav was made up as a 25 per cent solution and sterilized by passing the solution through a Seitz fllter. Commencing with a few milligrams, the dose was gradually increased to $1 \mathrm{gm}$. and afterwards to $2 \mathrm{gm}$. and $4 \mathrm{gm}$. Five men and one woman acted as the experimental subjects, and all the doses were given intravenously. There were no unpleasant symptoms or reactions, and since, after precautionary intradermal tests, several people received a second dose some weeks after the first, it is concluded that BAL-Intrav is essentially non-toxic for man, as it is for animals, and that it has no allergic properties. Very soon after its administration has begun some volatile component begins to be excreted through the lungs, and the subject can detect it by its smell. After doses of $1 \mathrm{gm}$. and more, the urine also has a distinct smell.

Since the value of BAL-Intrav as a chemotherapeutic agent depends upon its formation of a soluble compound with arsenic, we wondered to what extent it might also form soluble compounds with the heavy metals normally present in serum-iron, copper and zincand thereby increase their excretion in the urine. Urine was accordingly collected from the six subjects before and after administration of the BAL-Intrav and analysed for these metals. The drug increased the excretion of copper about twenty times, and that of zinc about details of these experiments are given in the table.

\begin{tabular}{|c|c|c|c|c|c|c|c|}
\hline \multirow{2}{*}{$\begin{array}{l}\text { Sub- } \\
\text { ject }\end{array}$} & \multirow{2}{*}{$\begin{array}{l}\text { Intravenous } \\
\text { dose }\end{array}$} & \multicolumn{6}{|c|}{ Urinary excretion ( $\mu \mathrm{gm}$. per hr.) } \\
\hline & & \multicolumn{2}{|c|}{ Iron } & \multicolumn{2}{|c|}{ Copper } & \multicolumn{2}{|c|}{ Zinc } \\
\hline \multirow{7}{*}{$\begin{array}{l}\text { R.M. } \\
\text { E.W. } \\
\text { A.W. } \\
\text { G.S. } \\
\text { G.W. } \\
\text { K.B. }\end{array}$} & \multirow{7}{*}{$\begin{array}{l}2 \mathrm{gm} . \mathrm{BAL}- \\
\text { Intrav } \\
2 \mathrm{gm} . \text { BAL- } \\
\text { Intrav } \\
4 \mathrm{gm} . \text { BAL- } \\
\text { Intrav } \\
4 \mathrm{gm} \text {. BAL- } \\
\text { Intrav } \\
4 \mathrm{gm} . \text { BAL- } \\
\text { Intrav } \\
4 \mathrm{gm} \text {. BAL- } \\
\text { Intrav }\end{array}$} & Before & After & Before & After & Before & After \\
\hline & & & & $3 \cdot 6$ & $65 \cdot 8$ & 39 & 178 \\
\hline & & & & $4 \cdot 6$ & $126 \cdot 0$ & 65 & 93 \\
\hline & & $36 \cdot 6$ & $67 \cdot 3$ & $6 \cdot 5$ & $235 \cdot 0$ & 58 & 585 \\
\hline & & $41 \cdot 2$ & $39 \cdot 7$ & $14 \cdot 0$ & $142 \cdot 0$ & 84 & 295 \\
\hline & & $51 \cdot 0$ & $53 \cdot 2$ & $9 \cdot 7$ & $206 \cdot 0$ & 111 & 527 \\
\hline & & $42 \cdot 9$ & $43 \cdot 2$ & $5 \cdot 7$ & $153 \cdot 0$ & 60 & 400 \\
\hline
\end{tabular}

The BAL-Intrav itself contained small amounts of copper and zinc; but it is impossible to make an accurate correction for this because of the uncertainty of knowing how much BAL-Intrav was excreted in the urine during the time of observation. Even if the
whole of the copper and zinc introduced with the BAL had left the whole of the copper and zinc introduced with the BAL had left the
body during the flrst hour, the correction to be applied would only be a minor one and would not materially alter the conclusions. R. A. MCCANCE
E. M. WIDDOWSON

Department of Experimental Medicine, Cambridge.

${ }^{1}$ Danielli, J. F., Danielli, M., Mitchell, P. D., Owen, L. N., and Shaw, G., Nature, 157, 217 (1946).

\section{Effect of BAL-Intrav on Excretion of Copper by the Sheep}

McCance and Widdowson ${ }^{1}$ have shown that intravenous injection of BAL-Intrav (dithioglycerol glucoside) increased greatly the urinary exeretion of copper in man. In view of the importance of naturally occurring diseases in sheep associated with either a defleiency of copper (for example, enzootic ataxia ${ }^{2}$ or 'swayback' of lambs) or an excessive storage of copper (for example, toxæmic jaundice ${ }^{3}$ ), preliminary trials were made to ascertain whether, in sheep, BAL-Intrav would similarly influence the excretion of copper. It was felt that the experimental use of this substance and of related compounds might prove of value in the elucidation of some of the unsolved problems associated with the copper metabolism of the sheep.

Under suitable restraint, the bladder was emptied by catheter and washed by injection of warm, sterile saline solution. After a control period, the urine was collected and the solution of BAL-Intrav was injected intramuscularly. At regular periods thereafter the urine was collected. Precautions were taken to avoid contamination of the urine by copper. Analyses for copper were performed, after digestion with sulphuric, perchloric and nitric acids, by the development of

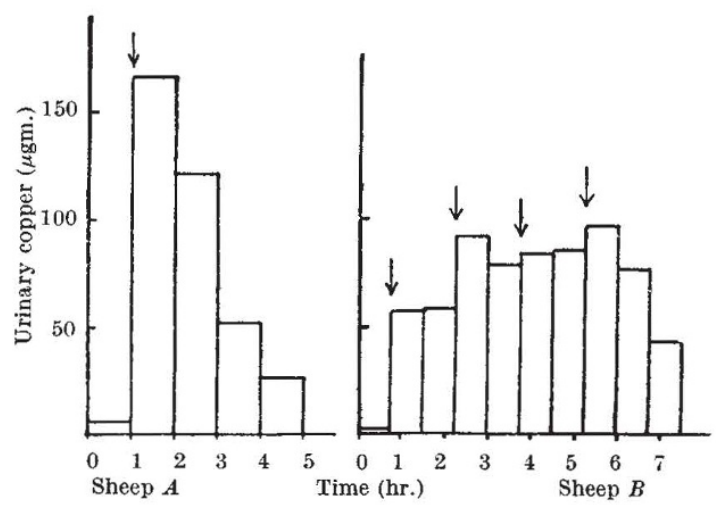

GRAPHS SHOWING EFFECT ON URINARY EXCRETION OF COPPER FOLLOWING INTRAMUSCULAR INJECTION (AT THE TIMES INDICATED BY THE ARROWS) OF ( $A$ ) A SINGLE DOSE OF 4 GM. BAL-INTRAV

(B) 4 DOSES, EACH OF 1 GM., OF BAL-INTRAV

tion of Clare et al. 4 Corrections were made for the copper present in the BAL-Intrav solution.

The data presented graphically show that the rate of excretion of copper was increased to some thirty times the normal value. With the larger dose, excretion reached a maximum during the first hour after injection and fell rapidly during succeeding hours; with the smaller, repeated doses, high levels of excretion were maintained. BAL-Intrav produced no apparent deleterious effects and was rapidly excreted in the urine. Data for the toxic dose of BAL-Intrav in the sheep are not available, but it is probable that the doses used (namely, $0.1 \mathrm{gm} . / \mathrm{kgm}$. and $0.04 \mathrm{gm} . / \mathrm{kgm}$.) are far below the toxic dose ; for the rat the lethal dose (L.D. 50 ) is about $7.5 \mathrm{gm} . / \mathrm{kgm} .^{5}$.

the rat the lethal dose (L.D. 50) is about $7.5 \mathrm{gm} . / \mathrm{kgm} .^{5}$.
Although the actual amount of excess copper excreted in these Although the actual amount of excess copper excreted in these
two cases was quite small (approximately $300 \mu \mathrm{gm}$. and $600 \mu \mathrm{gm}$., two cases was quite small (approximately $300 \mu \mathrm{gm}$. and $600 \mu \mathrm{gm}$.,
during the periods measured), the excretion could probably be greatly increased by the use of larger doses, frequent or continuous injections, or possibly by the concurrent use of BAL (dithioglycerol) with BAL. or possi

School of Biochemistry,

IAN Wr MCDONALD Cambridge.
May 18.

${ }^{1}$ McCance, R. A., and Widdowson, E. M., see preceding communication. ${ }^{2}$ Bennetts, H. W., and Beck, A. B., Coun. Sei. Ind. Res. (Aust.) Bull. 147 (1942).

3 Albiston, H. E., Bull, L. B., Dick, A. T., and Keast, J. C., Aust. Vet. J., 16, $233(1940)$.

, N. T., Cunningham, I. J., and Perrin, D. D., N.Z. J. Sci. Tech. $26,340(1945)$ G., Nature, 157, 217 (1946).
anielli, J. F., Danielli, M., Mitchell, P. D., Owen, L. N., and Shaw,

\section{Inactivation of Thrombin}

BARRATT ${ }^{1}$ found in 1932 that bacteria do not cause the decomposition of thrombin preparations, but rather that this is a chemical process I have shown that the inactivation of thrombin in native blood and in the pure thrombin solution is the same process as that which is caused by an inactivating system in plasma, but which in the preparaThe present as an impurity.

The inactivation effect of blood is relatively high. $1 \mathrm{ml}$. of native blood mixed with 100 units of thrombin causes about 99 per cent inactivation in 10 minutes. ( 1 unit is the quantity of thrombin which clots $1 \mathrm{ml}$. of blood in 1 minute at $20^{\circ} \mathrm{C}$.) This inactivator could destroy a much greater quantity of thrombin equally well.

The inactivation of thrombin ('transformation to metathrombin') is considered by some investigators as adsorption ${ }^{2}$, by others as the effect of a dialysable substance ${ }^{3}$. I have demonstrated on the basis of reactionkinetic experiments that neither of these views can be accepted. inactivation is due to two parallel and separate causes, namely, sudden adsorption, and a fermentative inactivating process (Fig, 1). Thrombin adsorption is reversible. At a low concentration it follows the Langmuir adsorption isotherm; but at a high concentration it shows deviations from this law. Increase of temperature diminishes the adsorption, and the presence of chloroform or alcohols hinders it. Thrombin inactivation due to the effect of ferments follows a monomolecular reaction type $\left(k, 0.4-0.5\right.$ at $20^{\circ} \mathrm{C}$.). Increase of temperature increases the power of the, inactivator. If we increase the temperature by $10^{\circ} \mathrm{C}$. the value of $k$ is increased $2-2.5$ times. higher temperatures $\left(58-60^{\circ} \mathrm{C}\right.$.) the inactivator ceases to function. At Metals (Al,,$++ \mathrm{Fe}+++$ ) accelerate, metal-binding to function. the effect of the inactivator. After dialysis the inactivating capacity of the plasma diminishes without the dialysing water showing the effect of inactivation. If, however, we added the dialysing water to the dialysed plasma again, the plasma regains its original water to for inactivation. The observed phenomena show that the inactivator has the characteristics of a ferment.

During clotting (due to the effects of inactivation) $1 \mathrm{mI}$. of blood I found that $1 \mathrm{ml}$. of blood contain ; on eliminating the inactivato 